\title{
ANALISIS FINANSIAL USAHA TERNAK SAPI BALI (Bos sondaicus) DI P4S CAHAYA PURNAMA KABUPATEN KUTAI TIMUR
}

\author{
(Financial Analysis Of Bali Cattle (Bos sondaicus) Farming In P4S of Cahaya Purnama At East \\ Kutai District)
}

\author{
Al Hibnu Abdillah' ${ }^{1}$,Juraemi², Taufan Purwokusumaning Daru ${ }^{3}$ \\ ${ }^{1}$ Program Studi Agroteknologi Sekolah Tinggi Pertanian Kutai Timur \\ Jl. Soekarno-Hatta No.1, Sangatta, Kutai Timur \\ 2 Program Studi Agribisnis Universitas Mulawarman, Jl. Paser Belengkong, Samarinda \\ ${ }^{3}$ Program Studi Peternakan Universitas Mulawarman Jl. Paser Belengkong, Samarinda \\ Email : alhibnu_abdillah@stiperkutim.ac.id ; taufan.pd@gmail.com
}

Article Submitted : 27-02-2019

Article Accepted : 04-04-2019

\begin{abstract}
Since it was established in 2010 until 2016, Bali cattle farming and its byproduct of the Agricultural and Rural Training Center (P4S = Pusat Pelatihan Pertanian dan Pedesaan Swadaya) had never been evaluated for its financial analysis. This research aimed to evaluate the financial analysis of Bali cattle farming and its byproduct in the P4S of Cahaya Purnama. This research was conducted from September to December 2016 in the P4S of Cahaya Purnama, Tepian Baru Village, Bengalon Sub-district, East Kutai District. The sample was taken by using purposive sampling method with the criterion that the cattle were 8 to 24 months old. The instruments used to analyze the data were Net Present Value (NPV), Internal Rate of Return (IRR), Net Benefit/Cost Ratio, Payback Period and Return of Investment (ROI). Bali cattle farming business consisted of the development of Bali beef cattle as the main business and manure processing as the byproduct. Manure processing business was the attempt of the manager to utilize the waste of cattle and it was expected that it was able to add income for the farmers. The model of Bali cattle development was the integration between oil palm plantation and Bali cattle farming. The research findings showed that the NPV was $9 \%$, indicating that the business was minus with the amount of Rp. 19,393,858, so that the value of IRR was not known. The value of Net B/C Ratio was 0.97 ; the value of payback period was 0.83 or 9 years; and the value of ROI was minus with the percentage of $19 \%$. Therefore, the Bali cattle farming business was not feasible to continue and there should be some improvements needed to make it better.
\end{abstract}

Keywords: cattle, manure, financial analysis, $N P V$

\section{PENDAHULUAN}

Daging sapi adalah produk pertanian yang menjanjikan dan memiliki daya minat yang tinggi. Komposisi daging sapi terdiri atas air, lemak, protein, mineral, dan karbohidrat. Kandungan gizi yang lengkap dan keanekaragaman produk olahannya menjadikan daging sapi sebagai bahan pangan yang tidak dapat dipisahkan dari kehidupan manusia (Prasetyo, et.al,. 2013). Kecamatan Bengalon merupakan satu dari delapan belas kecamatan di Kabupaten Kutai Timur. Konsumsi daging sapi penduduk di Kecamatan Bengalon mengalami fluktuatif. Berdasarkan data dari Dinas Pertanian dan Peternakan Kabupaten Kutai Timur (2016), konsumsi daging sapi pada tahun 2012, 2013, 2014, 2015 sebesar $9.455,10 \mathrm{~kg}, 21.907,67$ $\mathrm{kg}, \quad 18.313,07 \mathrm{~kg}, \quad 11.725 \mathrm{~kg}$. Jumlah 
konsumsi sedemikian besar ini tentunya harus diimbangi dengan jumlah produksi daging sapi yang tinggi. Produksi daging sapi di Kabupaten Kutai Timur pada tahun 2012, 2013, 2014, 2015 sebesar $9.952 \mathrm{~kg}$, $23.060,70 \mathrm{~kg}, \quad 19.276,92,12.342,11 \mathrm{~kg}$. (Dinas Pertanian dan Peternakan Kabupaten Kutai Timur, 2016).

Pusat Pelatihan Pertanian Pedesaan dan Swadaya (P4S) Cahaya Purnama Desa Tepian Baru adalah satu dari beberapa P4S yang tersebar di daerah Kalimantan Timur. Bermula dari kelompok tani yang kemudian melakukan penggabungan menjadi Gabungan Kelompok Tani (GAPOKTAN), hingga kemudian mengusulkan pembentukan P4S. P4S ini bergerak dalam bidang kegiatan agribisnis yang berfokus pada integrasi kelapa sawit dengan sapi. Sistem ini selalu digalakkan oleh Dinas Pertanian Provinsi Kalimantan Timur, dan telah mendapatkan respon positif sehingga banyak diterapkan oleh para pekebun kelapa sawit. Sinergi antara kelapa sawit dan sapi, agar gulma di areal kelapa sawit bisa dikendalikan oleh sapi, berdampak pada penekanan biaya pengendalian gulma. Bagi sapi keuntungannya adalah pakan berupa gulma yang tersedia, sehingga biaya pemberian pakan bisa dikurangi. Tujuan penelitian ini adalah melakukan evaluasi analisis finansial usaha ternak Sapi Bali (Bos Sondaicus) di Pusat Pelatihan Pertanian Pedesaan dan Swadaya (P4S) Cahaya Purnama di Desa Tepian Baru Kecamatan Bengalon Kabupaten Kutai Timur.

\section{METODE PENELITIAN}

Penelitian ini dilaksanakan selama tiga bulan terhitung dari bulan September sampai bulan Desember 2016. Lokasi penelitian di P4S Cahaya Purnama, Desa Tepian Baru, Kecamatan Bengalon, Kabupaten Kutai Timur, Provinsi Kalimantan Timur. Metode pengambilan sampel menggunakan teknik purposive sampling, yakni mengambil sampel dengan pertimbangan tertentu dari peneliti (Sugiyono, 2014). Adapun sapi yang diambil sampelnya dihitung berdasarkan umur sapi, yakni dari umur 8 hingga 24 bulan. Jumlah sapi yang dihitung sebanyak 103 ekor. Sapi yang diambil sampelnya diasumsikan dibeli dan terjual habis di tahun tersebut. Menghitung analisis finansial berdasarkan studi kelayakan menggunakan analisis deskritif dengan menggunakan standar kelayakan bisinis.

\section{Net Present Value (NPV)}

Menurut Kadariah (1990) dalam Handayanta, et al., (2013), Net Present Value (NPV) dapat dihitung dengan rumus:

$\mathrm{NPV}=\sum_{t=1}^{n} \frac{B t-C t}{(1+i)^{t}}$

Keterangan :

$\mathrm{Bt}$ : jumlah penerimaan kotor dari usaha pada tahun $\mathrm{t}$

$\mathrm{Ct}$ : jumlah pengeluaran kotor dari usaha pada tahun $\mathrm{t}$

$\mathrm{n}:$ umur ekonomis

$\mathrm{i}$ : tingkat suku bunga (\%)

\section{Internal Rate of Return (IRR)}

Menurut Kadariah (1990) dalam Handayanta, et al., (2013), Internal Rate of Return (ROI) dapat dihitung dengan rumus:

$\mathrm{IRR}=\mathrm{i}_{1}+\frac{\mathrm{NPV}_{1}}{\mathrm{NPV}_{1}-\mathrm{NPV}_{2}}\left(\mathrm{i}_{1}-\mathrm{i}_{2}\right)$

\section{Net Benefit/Cost Ratio (Net B/C Ratio)}

Menurut Nurmalina, et al., (2010)

dalam Zaini dan Bustomi (2017), Net B/C Ratio dapat dihitung dengan rumus:

Net B/C

$=\frac{\sum_{\mathrm{t}=1}^{\mathrm{n}}=\frac{(\mathrm{Bt}-\mathrm{Ct})}{(1+\mathrm{i})^{\mathrm{t}}}}{\sum_{\mathrm{t}=1}^{\mathrm{n}}=\frac{(\mathrm{Bt}-\mathrm{Ct})}{(1+\mathrm{i})^{\mathrm{t}}}} \quad$ Dimana $\quad \frac{(\mathrm{Bt}-\mathrm{Ct})>0}{(\mathrm{Bt}-\mathrm{Ct})<0}$

Keterangan:

$\mathrm{Bt}=$ Manfaat yang diperoleh pada tahun ke- $\mathrm{t}$

$\mathrm{Ct}=$ Biaya yang dikeluarkan pada tahun ke- $\mathrm{t}$

$\mathrm{i}=$ Tingkat suku bunga $(\%)$

$\mathrm{t}=$ Tahun ke-

$\mathrm{n}=$ Umur usaha 


\section{Payback Period}

Menurut Kadariah (1990) dalam Handayanta, et al., (2013), Payback Period (PBP) dapat dihitung dengan rumus:

Payback Period $=\frac{\mathrm{I}}{\mathrm{Ab}}$

Keterangan:

$\mathrm{I}=$ Besarnya biasa investasi yang diusahakan $\mathrm{Ab}=$ Benefit bersih yang dapat diperoleh usaha pada setiap tahunnya

\section{Return Of Investment (ROI)}

Menurut Kadariah (1990) dalam Handayanta, et al., (2013), Return Of Investment (ROI) dapat dihitung dengan rumus:

ROI $=\frac{\text { Laba usaha }}{\text { Jumlah investasi }} \times 100 \%$

\section{HASIL DAN PEMBAHASAN}

Pusat Pelatihan Pertanian Pedesaan dan Swadaya (P4S) Cahaya Purnama Desa
Tepian Baru adalah satu dari beberapa P4S yang tersebar di daerah Kalimantan Timur. Bermula dari beberapa kelompok tani yang kemudian melakukan penggabungan menjadi Gabungan Kelompok Tani (GAPOKTAN). GAPOKTAN berdiri pertama kali pada 22 Februari 2008. Seiring berjalannya waktu dengan mempertimbangkan perluasan usaha GAPOKTAN yang telah ada, diusulkanlah untuk menjadi Pusat Pengembangan Pendidikan Pelatihan Terpadu (P4S) pada 3 Maret 2015. Pada 30 Desember 2015 terbitlah Surat Keputusan (SK) dari Badan Ketahanan Pangan dan Penyuluhan (BKPP) Provinsi Kalimantan Timur, dengan nomor 420.1538/SK.P4S/PENY-BKPP, yang menetapkan berdirinya P4S Cahaya Purnama Tepian Baru. Berdasarkan data yang diperoleh diketahui bahwa jumlah sapi yang diternakkan berfluktuatif setiap tahunnya. Berikut adalah data jumlah sapi umur 8 hingga 24 bulan.

Tabel 1. Data Sampel Sapi Tahun 2010 hingga 2016 (ekor)

\begin{tabular}{ccccccccc}
\hline Tahun & 2010 & 2011 & 2012 & 2013 & 2014 & 2015 & 2016 & Jumlah \\
\hline Jantan & 1 & 3 & 1 & 0 & 1 & 6 & 8 & 20 \\
Betina & 4 & 10 & 8 & 1 & 13 & 35 & 12 & 83 \\
\hline Jumlah & 5 & 13 & 9 & 1 & 14 & 41 & 20 & 103 \\
\hline
\end{tabular}

\section{Sistem Integrasi Kelapa Sawit dan Sapi}

Pengelola menggunakan sistem integrasi kelapa sawit dan sapi. Sapi dipelihara dengan cara semi intensif, dimana pada waktu pagi dari pukul 10.00 WITA hingga 15.00 WITA dilepaskan di areal budidaya kelapa sawit. Sapi dikembalikan dikandangkan dari pukul 17.30 WITA hingga 10.00 WITA. Hal ini sesuai dengan pendapat Sugeng (1996) dalam Darmawi (2011), yang menyatakan sistem pemeliharaan semi intensif, yaitu pada siang hari ternak dilepas dikebun atau pekarangan yang rumputnya tumbuh subur, kemudian sore harinya ternak dimasukkan dalam kandang dan pada malam hariya ternak diberi minum berupa hijauan/rumput atau dedaunan. Pola integrasi antara tanaman kelapa sawit dan sapi memiliki hubungan yang saling menguntungkan. Pendapatan yang diperoleh mencakup penurunan biaya pakan untuk sapi, dan biaya pengendalian gulma bagi tanaman kelapa sawit. Kondisi ini tercermin pada data yang tertera sebagai berikut:

Tabel 2. Data Perbandingan Biaya Antara Sistem Intergrasi Kelapa Sawit-Sapi

\begin{tabular}{lccc}
\hline \multicolumn{1}{c}{ Rincian } & $\begin{array}{c}\text { Biaya Pakan Rumput } \\
\left(\mathrm{Rp} \mathrm{kg}^{-1}\right)\end{array}$ & $\begin{array}{c}\text { Biaya Tenaga Kerja } \\
\left(\mathrm{Rp} \mathrm{ha}^{-1}\right)\end{array}$ & $\begin{array}{c}\text { Biaya Herbisida } \\
\left(\mathrm{Rp} \mathrm{ha}^{-1}\right)\end{array}$ \\
\hline Tanpa Integrasi & 3.000 & 128.000 & 0 \\
Integrasi & 1.000 & 140.000 & 0 \\
\hline
\end{tabular}


Kondisi ini sesuai dengan penelitian terdahulu oleh Panggasa (2017), bahwa sistem integrasi tanaman kelapa sawit dan sapi di P4S Cahaya Purnama dilakukan dengan model pemanfaatan hijauan (rumput/legum) atau tanaman penutup tanah yang tumbuh di areal kebun kelapa sawit. Pemanfaatan dilakukan dengan melepas ternak secara terencana dari jam 10.00 WITA hingga 15.00 WITA. Dengan pola semi intensif maka pemberian pakan kepada sapi hanya sekali sehari, yakni saat sapi masuk kandang pada jam 15.00 WITA. Pengelola meyakini bahwa pakan untuk sapi telah tersedia di areal kelapa sawit sebesar $80 \%$ yang dibutuhkan, sedangkan $20 \%$ adalah pakan pemberian dikandang berupa rumput gajah. Sistem integrasi mampu menekan biaya pakan sekitar $50-70 \%$. Kondisi ini selaras dengan penelitian yang dilakukan Utomo dan Widjaja (2007), bahwa sistem integrasi mampu mengurangi biaya pakan hingga menjadi Rp.1.145 ekor hari ${ }^{-1}$, dan terjadi efisiensi harga rumput sebesar $54,4 \%$. Manfaat yang diterima dari sistem integrasi tanaman kelapa sawit dan sapi seiring dengan pendapat Panggasa (2008) dalam Panggasa (2017), bahwa lahan perkebunan sawit dapat menyediakan penutup tanah sebagai sumber pakan ternak, guna mengoptimalkan pemberdayaan lahan melalui sistem integrasi tanaman kelapa sawit dan sapi. Penanaman rumput dan legum sebagai sumber pakan ternk di sela-sela tanaman kelapa sawit. Adapun manfaat yang didapatkan oleh kelapa sawit adalah:

1. Meniadakan biaya tenaga kerja dan herbisida

2. Tanaman mendapatkan pupuk alami dari kotoran sapi

Manfaat ini sesuai dengan pendapat Panggasa (2017), bahwa penggunaan sapi sebagai tenaga kerja di areal kebun sawit mampu menjadi penghasil pupuk untuk tanaman kelapa sawit. Pola integrasi mampu memberikan pendapatan bagi kedua pihak tersebut. Kondisi ini selaras dengan hasil penelitian yang dilakukan oleh Daru, et al., (2014), yang menyatakan bahwa keberadaan ternak di perkebunan kelapa sawit memberikan beberapa pendapatan, diantaranya adalah mengurangi biaya untuk mengendalikan gulma dan menyumbangkan kotoran ternak sebagai sumber hara bagi tanaman. Hijauan antara tanaman di perkebunan kelapa sawit memiliki potensi yang besar sebagai sumber hijauan bagi sapi potong. Sistem integrasi sapi dan kelapa sawit di P4S Cahaya Purnama memiliki dampak yang positif antar kedua komoditi tersebut. Hal ini sesuai dengan hasil penelitian yang dilakukan oleh Matondang dan Talib (2015), yang menyatakan bahwa tingkat fertilitas yang tinggi, dan mampu beradaptasi dengan baik pada lingkungan perkebunan sawit. Selain itu memberikan tambahan penghasilan dari hasil penjualan sapi, memanfaatkan kotoran sapi sebagai pupuk organik dan mengurangi jumlah tenaga kerja.

\section{Usaha Ternak Sapi Bali \\ Biaya Tenaga Kerja}

Pengelola P4S Cahaya Purnama mempekerjakan tenaga kerja sesuai jumlah sapi yang dipelihara. Setiap sepuluh ekor sapi yang diternakkan menggunakan tenaga kerja sebanyak satu orang. Upah per hari sebesar Rp 100.000, dengan jam kerja selama 8 jam. Tenaga mantri hewan dihitung per ekor, yakni Rp 10.000 per ekor. Konsumsi bagi para pekerja telah termasuk dalam upah tersebut. Biaya tenaga kerja bisa dilihat pada tabel 4 . 
Tabel 4. Biaya Tenaga Kerja Usaha Ternak Sapi Bali (Rp)

\begin{tabular}{cccc}
\hline Tahun & Biaya Tenaga Kerja & $\begin{array}{c}\text { Biaya Tenaga Mantri } \\
\text { Hewan }\end{array}$ & Jumlah \\
\hline 2010 & 9.000 .000 & 150.000 & 9.150 .000 \\
2011 & 30.000 .000 & 650.000 & 30.650 .000 \\
2012 & 12.000 .000 & 360.000 & 12.360 .000 \\
2013 & 9.000 .000 & 120.000 & 9.120 .000 \\
2014 & 30.000 .000 & 700.000 & 30.700 .000 \\
2015 & 120.000 .000 & 4.100 .000 & 124.100 .000 \\
2016 & 36.000 .000 & 1.200 .000 & 37.200 .000 \\
\hline Jumlah & 246.000 .000 & 7.280 .000 & 253.280 .000 \\
\hline
\end{tabular}

Biaya Operasional Pemeliharaan Ternak

Ternak yang baik memiliki konidisi sehat dan memiliki kondisi yang kuat. Agar mencapai hal itu diperlukan pemeliharaan yang rutin. Pengelola mengeluarkan biaya biaya pada tabel berikut:

Tabel 5. Biaya Operasional Usaha Ternak Sapi Bali (Rp)

\begin{tabular}{|c|c|c|c|c|c|c|c|}
\hline Rincian & 2010 & 2011 & 2012 & 2013 & 2014 & 2015 & 2016 \\
\hline $\begin{array}{l}\text { Pembelian } \\
\text { sapi jantan }\end{array}$ & 7.000 .000 & 21.000 .000 & 7.000 .000 & - & 7.000 .000 & 42.000 .000 & 56.000 .000 \\
\hline $\begin{array}{l}\text { Pembelian } \\
\text { sapi betina }\end{array}$ & 20.000 .000 & 50.000 .000 & 40.000 .000 & 5.000 .000 & 65.000 .000 & 175.000 .000 & 60.000 .000 \\
\hline $\begin{array}{l}\text { Hijauan } \\
\text { rumput } \\
\text { gajah }\end{array}$ & 9.000 .000 & 23.400 .000 & 16.200 .000 & 1.800 .000 & 25.200 .000 & 73.800 .000 & 36.000 .000 \\
\hline Vitamin & 360.000 & 360.000 & 360.000 & 360.000 & 360.000 & 360.000 & 360.000 \\
\hline $\begin{array}{l}\text { Solar } \\
\text { traktor }\end{array}$ & 1.260 .000 & 1.260 .000 & 1.260 .000 & 1.260 .000 & 1.260 .000 & 1.260 .000 & 1.260 .000 \\
\hline $\begin{array}{l}\text { Bensin } \\
\text { untuk } \\
\text { perawatan } \\
\text { sapi }\end{array}$ & 315.000 & 525.000 & 420.000 & 315.000 & 525.000 & 1.050 .000 & 630.000 \\
\hline $\begin{array}{l}\text { Solar } \\
\text { genset } \\
\text { listrik }\end{array}$ & 199.500 & 332.500 & 266.000 & 199.500 & 332.500 & 665.000 & 399.000 \\
\hline $\begin{array}{l}\text { Solar } \\
\text { mesin } \\
\text { pencacah } \\
\text { rumput }\end{array}$ & 1.890 .000 & 3.150 .000 & 2.520 .000 & 1.890 .000 & 3.150 .000 & 6.300 .000 & 3.780 .000 \\
\hline Biotriba & 765.000 & 1.989 .000 & 1.377 .000 & 153.000 & 2.142 .000 & 6.273 .000 & 3.060 .000 \\
\hline $\begin{array}{l}\text { Gula } \\
\text { merah }\end{array}$ & 540.000 & 1.404 .000 & 972.000 & 108.000 & 1.512 .000 & 4.428 .000 & 2.160 .000 \\
\hline Karung & 450.000 & 1.170 .000 & 810.000 & 90.000 & 1.260 .000 & 3.690 .000 & 1.800 .000 \\
\hline Jumlah & 40.249 .500 & 103.120 .500 & 69.685 .000 & 9.960 .500 & 106.796 .500 & 314.556 .000 & 164.639 .000 \\
\hline
\end{tabular}

Biaya Alat dan Penyusutan

Alat adalah benda yang digunakan untuk menunjang kegiatan operasional yang bersifat tidak habis pakai dalam sekali penggunaan. Penyusutan adalah perhitungan untuk mengetahui berapa besar nilai alat mengalami susut dalam tiap tahunnya. Kegiatan pengelolaan sapi potong menggunakan alat-alat sebagai berikut: 
Tabel 6. Biaya Alat Usaha Ternak Sapi Bali (Rp)

\begin{tabular}{|c|c|c|c|c|c|c|c|}
\hline Rincian & 2010 & 2011 & 2012 & 2013 & 2014 & 2015 & 2016 \\
\hline Kandang & 95.000 .000 & - & - & - & - & - & - \\
\hline Cangkul & 240.000 & - & - & 240.000 & - & - & 240.000 \\
\hline Arit & 300.000 & - & - & 300.000 & - & - & 300.000 \\
\hline $\begin{array}{l}\text { Parang } \\
\text { Malaysia }\end{array}$ & 150.000 & - & - & 150.000 & - & - & 150.000 \\
\hline Handtraktor & 15.000 .000 & - & - & - & - & - & - \\
\hline $\begin{array}{l}\text { Mesin } \\
\text { Pencacah } \\
\text { Rumput }\end{array}$ & - & - & - & 12.000 .000 & - & - & - \\
\hline $\begin{array}{l}\text { Sprayer } \\
\text { Solo }\end{array}$ & 600.000 & - & - & - & - & 600.000 & - \\
\hline Ember & 60.000 & 60.000 & 60.000 & 60.000 & 60.000 & 60.000 & 60.000 \\
\hline Terpal & 1.200 .000 & & 1.200 .000 & & 1.200 .000 & & 1.200 .000 \\
\hline Jumlah & $\begin{array}{c}122.550 .00 \\
0\end{array}$ & 60.000 & 1.260 .000 & 12.750 .000 & 12.600 .000 & 660.000 & 1.950 .000 \\
\hline
\end{tabular}

Tabel 7. Biaya Penyusutan Usaha Ternak Sapi Bali (Rp)

\begin{tabular}{|c|c|c|c|c|c|c|c|}
\hline Rincian & 2010 & 2011 & 2012 & 2013 & 2014 & 2015 & 2016 \\
\hline Kandang & 6.333 .333 & 6.333 .333 & 6.333 .333 & 6.333 .333 & 6.333 .333 & 6.333 .333 & 6.333 .333 \\
\hline Cangkul & 80.0000 & 80.0000 & 80.0000 & 80.0000 & 80.0000 & 80.0000 & 80.0000 \\
\hline Arit & 100.000 & 100.000 & 100.000 & 100.000 & 100.000 & 100.000 & 100.000 \\
\hline $\begin{array}{l}\text { Parang } \\
\text { malaysia }\end{array}$ & 50.000 & 50.000 & 50.000 & 50.000 & 50.000 & 50.000 & 50.000 \\
\hline Handtraktor & 1.000 .000 & 1.000 .000 & 1.000 .000 & 1.000 .000 & 1.000 .000 & 1.000 .000 & 1.000 .000 \\
\hline $\begin{array}{l}\text { Mesin } \\
\text { pencacah } \\
\text { rumput }\end{array}$ & - & - & - & 800.000 & 800.000 & 800.000 & 800.000 \\
\hline $\begin{array}{l}\text { Sprayer } \\
\text { solo }\end{array}$ & 120.000 & 120.000 & 120.000 & 120.000 & 120.000 & 120.000 & 120.000 \\
\hline Ember & 60.000 & 60.000 & 60.000 & 60.000 & 60.000 & 60.000 & 60.000 \\
\hline Terpal & 600.000 & 600.000 & 600.000 & 600.000 & 600.000 & 600.000 & 600.000 \\
\hline Jumlah & 8.343 .333 & 8.343 .333 & 8.343 .333 & 9.143 .333 & 9.143 .333 & 9.143 .333 & 9.143 .333 \\
\hline
\end{tabular}

Total Biaya Usaha Ternak Sapi Bali

Secara keseluruhan biaya untuk usaha ternak sapi telah diketahui. Langkah selanjutnya adalah menjumlahkan secara

Tabel 8. Total Biaya Usaha Ternak Sapi Bali (Rp)

\begin{tabular}{ccccc}
\hline Tahun & $\begin{array}{c}\text { Biaya Tenaga } \\
\text { Kerja }\end{array}$ & $\begin{array}{c}\text { Biaya } \\
\text { Pemeliharaan } \\
\text { Ternak }\end{array}$ & Biaya Penyusutan & Jumlah \\
\hline 2010 & 9.150 .000 & 40.249 .500 & 8.343 .333 & 57.742 .833 \\
2011 & 30.650 .000 & 103.120 .500 & 8.343 .333 & 142.113 .833 \\
2012 & 12.360 .000 & 69.685 .000 & 8.343 .333 & 90.388 .333 \\
2013 & 9.120 .000 & 9.960 .500 & 9.143 .333 & 28.223 .833 \\
\hline
\end{tabular}

keseluruhan nilai jumlah untuk tiap sub bagian yang telah dibagi sebelumnya. Detail perhitungan ada pada tabel dibawah ini. 


\begin{tabular}{ccccc}
\hline 2014 & 30.700 .000 & 106.796 .500 & 9.143 .333 & 146.639 .833 \\
2015 & 124.100 .000 & 314.556 .000 & 9.143 .333 & 447.799 .333 \\
2016 & 37.200 .000 & 164.639 .000 & 9.143 .333 & 210.982 .333 \\
\hline Jumlah & 253.280 .000 & 840.007 .000 & 61.603 .333 & 1.123 .890 .333 \\
\hline
\end{tabular}

\section{Penerimaan dan Pendapatan}

Semua sapi yang dibeli dan diternakkan diasumsikan terjual semua. Harga sapi berbeda sesuai dengan jenis kelamin yang ditawarkan. Harga jual sapi jantan Rp 12.000.000, sementara sapi betina $\mathrm{Rp}$ 7.000.000. Sebagai produk sampingan, pihak pengelola berupaya untuk mengolah kotoran menjadi pupuk yang menghasilkan nilai tambah. Semakin banyaknya sapi akan berdampak pada besarnya pupuk yang diolah dan dijual. Dengan rincian biaya diatas diyakini akan mendapatkan hasil yang besar. Data pemasukan penjualan dan pendapatan pupuk kandang terlampir dibawahini:

Tabel 9. Penerimaan Usaha Usaha Ternak Sapi Bali (Rp)

\begin{tabular}{ccccc}
\hline \multirow{2}{*}{ Tahun } & $\begin{array}{c}\text { Penjualan } \\
\text { Sapi Jantan }\end{array}$ & $\begin{array}{c}\text { Penjualan } \\
\text { Sapi Betina }\end{array}$ & $\begin{array}{c}\text { Penjualan } \\
\text { Pupuk Kandang }\end{array}$ & Jumlah \\
\hline 2010 & 12.000 .000 & 28.000 .000 & 13.500 .000 & 53.500 .000 \\
2011 & 36.000 .000 & 70.000 .000 & 35.100 .000 & 141.100 .000 \\
2012 & 12.000 .000 & 56.000 .000 & 24.300 .000 & 92.300 .000 \\
2013 & - & 7.000 .000 & 2.700 .000 & 9.700 .000 \\
2014 & 12.000 .000 & 91.000 .000 & 37.800 .000 & 140.800 .000 \\
2015 & 72.000 .000 & 245.000 .000 & 110.700 .000 & 427.700 .000 \\
2016 & 96.000 .000 & 84.000 .000 & 54.000 .000 & 234.000 .000 \\
\hline Jumlah & 240.000 .000 & 581.000 .000 & 278.100 .000 & 1.099 .100 .000 \\
\hline
\end{tabular}

Tabel 10. Pendapatan Usaha Ternak Sapi Bali (Rp)

\begin{tabular}{cccc}
\hline Tahun & Penerimaan & Biaya & Pendapatan \\
\hline 2010 & 53.500 .000 & 57.742 .833 & -4.242 .833 \\
2011 & 141.000 .000 & 142.113 .833 & -1.013 .833 \\
2012 & 92.300 .000 & 90.388 .333 & 1.911 .667 \\
2013 & 9.700 .000 & 28.223 .833 & -18.523 .833 \\
2014 & 140.800 .000 & 146.639 .833 & -5.839 .833 \\
2015 & 427.700 .000 & 447.799 .333 & -20.099 .333 \\
2016 & 234.000 .000 & 210.982 .333 & 23.017 .667 \\
\hline Jumlah & 1.099 .100 .000 & 1.123 .890 .333 & -24.790 .667 \\
\hline Rata-rata & 191.300 .000 & 165.012 .905 & 26.287 .095 \\
\hline
\end{tabular}

\section{Analisis Kelayakan Usaha Ternak Sapi Bali}

Tujuan analisis kelayakan adalah mengetahui apakah usaha ternak di P4S telah layak atau tidak secara finansial. Dalam analisis ini peneliti menggunakan discount factor (df) sebesar 9\% dengan jangka waktu usaha 7 tahun, terhitung dari tahun 2010 hingga 2016. Penggunaan discount factor (df) sebesar 9\% didasarkan pada suku bunga Kredit Ternak Sejahtera Bank Kaltim (http://bit.ly/2tKDuTC, diakes pada 21 Juli 2017). 
Tabel 11. Analisis Kelayakan Usaha Ternak Sapi Bali (Rp)

\begin{tabular}{cccc}
\hline $\begin{array}{c}\text { Analisis } \\
\text { Kelayakan }\end{array}$ & Nilai & Kriteria & Hasil \\
\hline NPV & -19.373 .858 & $\begin{array}{c}\text { NPV }>0= \\
\text { layak }\end{array}$ & Tidak layak \\
\hline IRR & $\begin{array}{c}\text { Tidak perlu dianalisa } \\
\text { karena nilai NPV telah } \\
\text { minus }\end{array}$ & $\begin{array}{c}\text { IRR }>\text { cost of } \\
\text { capital }=\text { layak }\end{array}$ & Tidak layak \\
\hline Net B/C Ratio & 0,97 & NPV $>1$ & Tidak layak \\
\hline $\begin{array}{c}\text { Payback } \\
\text { Period }\end{array}$ & 0,83 atau 9 tahun & $\begin{array}{c}\text { Payback Period } \\
<\text { usaha }=\text { layak }\end{array}$ & Tidak layak \\
\hline ROI & $-19 \%$ & $\begin{array}{c}\text { ROI }>\text { tingkat } \\
\text { bunga bank }\end{array}$ & Tidak layak \\
\hline
\end{tabular}

Sesuai dengan kriteria kelayakan finansial pada tabel 11 maka usaha ini belum layak, sehingga perlu untuk dievaluasi dan dikembangkan agar usaha ini menjadi lebih menguntungkan kedepannya. Secara garis besar usaha pembesaran sapi belum layak karena besarnya biaya yang dikeluarkan tidak diimbangi dengan nilai pemasukan. Usaha pupuk sebagai usaha sampingan tidak layak diteruskan jika dalam jumlah yang sedikit tanpa ada pesanan dari pihak lain. Ada beberapa faktor lain penyebab kerugian usaha, yakni:

1. Usaha ternak sapi bali tidak layak jika dilakukan dengan jumlah sapi yang sedikit.

2. Usaha pembesaran sapi semata-mata bukanlah sebuah pekerjaan utama

3. Saat ini pengelola P4S Cahaya Purnama belum kearah skala bisnis

\section{KESIMPULAN}

Berdasarkan penjelasan diatas diketahui bahwa usaha ternak sapi bali merupakan penggabungan usaha pembesaran sapi bali sebagai usaha utama, dan usaha pengolahan pupuk kandang sebagai usaha sampingan. Berdasarkan analisis finansial, nilai NPV 9\% usaha tersebut minus sebesar Rp 19.373.858, sehingga nilai IRR tidak diketahui. Nilai Net B/C Ratio 0,97, payback period 0,83 atau 9 tahun, dan nilai ROI minus sebesar 19\%. Usaha ternak sapi bali belum layak diteruskan dan perlu dilakukan pembenahan agar menjadi lebih baik lagi. Hal yang perlu mendapat perhatian adalah:

1. Pengelola harus mengurangi biaya-biaya di pos yang memerlukan biaya besar agar mampu menekan kerugian, seperti pengurangan tenaga kerja. Jika sebelumnya menggunakan dua orang tenaga kerja untuk mengelola dua puluh ekor sapi, maka perlu dikurangi menjadi satu orang tenaga kerja saja.

2. Pengelola harus menambah jumlah sapi lebih banyak lagi, agar seluruh biaya mampu tertutupi oleh penjualan pupuk kandang.

3. Limbah ternak sapi perlu dikembangkan menjadi produk lanjutan yang memiliki nilai jual yang lebih tinggi, misalnya bokashi dan pupuk cair.

\section{DAFTAR PUSTAKA}

Anonim. 2017. Kredit Ternak Sejahtera. "http://bit.ly/2tKDuTC" diakses pada tanggal 21 Juli 2017

Darmawi, D. 2011. Pendapatan Usaha Pemeliharaan Sapi Bali di Kabupaten Muaro Jambi. Jurnal Ilmiah Ilmu-Ilmu Peternakan. XIV "http://bit.ly/2u00ZTM", diakses pada 12 Juli 2017 
Daru, T.P., Yulianti, A. dan Widodo, E. 2014. Potensi Hijauan Di Perkebunan Kelapa Sawit Sebagai Pakan Sapi Potong Di Kabupaten Kutai Kartanegara. Pastura. 3 (2) “http://bit.ly/2tEzsb2" diakses pada 7 Juni 2017

Dinas Pertanian dan Peternakan Kabupaten Kutai Timur. 2012. DataTernak Kabupaten Kutai Timur 2011. Dinas Pertanian dan Peternakan Kabupaten Kutai Timur, Sangatta

Dinas Pertanian dan Peternakan Kabupaten Kutai Timur. 2013. Data Ternak Kabupaten Kutai Timur 2012. Dinas Pertanian dan Peternakan Kabupaten Kutai Timur, Sangatta

Dinas Pertanian dan Peternakan Kabupaten Kutai Timur. 2014. Data Ternak Kabupaten Kutai Timur 2013. Dinas Pertanian dan Peternakan Kabupaten Kutai Timur, Sangatta

Dinas Pertanian dan Peternakan Kabupaten Kutai Timur. 2015. Data Ternak Kabupaten Kutai Timur 2014. Dinas Pertanian dan Peternakan Kabupaten Kutai Timur, Sangatta

Dinas Pertanian dan Peternakan Kabupaten Kutai Timur. 2016. Data Ternak Kabupaten Kutai Timur 2015. Dinas Pertanian dan Peternakan Kabupaten Kutai Timur, Sangatta

Handayanta, E., Rahayu, E.T., dan Sumiyati, M. 2016. Analisis Finansial Usaha Peternakan Pembibitan Sapi Potong Rakyat Di Daerah Pertanian Lahan Kering, Studi Kasus di Wilayah Kecamatan Semin, Kabupaten Gunungkidul, Daerah Istimewa Yogyakarta. Sains Peternakan. 14 (1) "http://bit.ly/2v0mcBe" diakes pada 6 Juni 2017
Matondang, R.E., dan Talib, C. 2015. Model Pengembangan Sapi Bali dalam Usaha Integrasi di Perkebunan Kelapa Sawit. Pusat Penelitian dan Pengembangan Peternakan, Bogor. WARTAZOA. 25 (3) "http://bit.ly/2tEjihW" diakses pada 3 Juni 2017

Panggasa, Y. 2017. Model Usaha Ternak Integrasi Sawit-Ternak Sapi Potong di P4S Cahaya Purnama Kecamatan Bengalon Kabupaten Kutai Timur. Jurnal Pertanian Terpadu. V (1)

Prasetyo, H., Padaga, M.C., dan Sawitri, M.E. 2013. Kajian Kualitas Fisiko Kimia Daging Sapi di Pasar Kota Malang. Jurnal Ilmu dan Teknologi Hasil Ternak. $8 \quad$ (2) "http://bit.ly/2tEnoqx", diakses pada 19 Juli 2017

Sugiyono. 2014. Statistika Untuk Penelitian. Alfabeta, Bandung

Utomo, N.B., dan Widjaja, E. 2007. Integrasi Ternak Sapi Bali Dengan Perkebunanan Kelapa Sawit: 2. Analisis Finansial Pembibitan Sapi Potong Melalui Pendekatan Secara Terintegrasi. Seminar Nasional Teknologi Peternakan dan Veteriner. Bogor. 21-22 Agustus 2007. "http://bit.ly/2uyF9dQ" diakses pada 3 Juni 2017

Zaini, A., dan Bustomi, M.Z. 2017. Analisis Kelayakan Finansial Usahatani Singkong Gajah di Kecamataan Anggana Kabupaten Kutai Kartanegara. Jurnal Pertanian Terpadu. V (1) 